\title{
Optimization of self-mixing modulation in VCSELs for sensing applications
}

\author{
Larsson, David; Yvind, Kresten; Hvam, Jørn Märcher
}

Published in:

CLEO/Europe-EQEC 2009

Link to article, DOI:

10.1109/CLEOE-EQEC.2009.5192873

Publication date:

2009

Document Version

Publisher's PDF, also known as Version of record

Link back to DTU Orbit

Citation (APA):

Larsson, D., Yvind, K., \& Hvam, J. M. (2009). Optimization of self-mixing modulation in VCSELs for sensing applications. In CLEO/Europe-EQEC 2009 IEEE. https://doi.org/10.1109/CLEOE-EQEC.2009.5192873

\section{General rights}

Copyright and moral rights for the publications made accessible in the public portal are retained by the authors and/or other copyright owners and it is a condition of accessing publications that users recognise and abide by the legal requirements associated with these rights.

- Users may download and print one copy of any publication from the public portal for the purpose of private study or research.

- You may not further distribute the material or use it for any profit-making activity or commercial gain

- You may freely distribute the URL identifying the publication in the public portal

If you believe that this document breaches copyright please contact us providing details, and we will remove access to the work immediately and investigate your claim. 


\title{
Optimization of self-mixing modulation in VCSELs for sensing applications
}

\author{
David Larsson, Kresten Yvind, and Jørn M. Hvam \\ Department of Photonics Engineering, NanoDTU, Technical University of Denmark, 2800 Kgs Lyngby, Denmark
}

Light that is fed back into a laser, so-called self-mixing interference (SMI), can have detrimental effects when the laser is used in optical communications [1]. On the other hand SMI can also be used to measure distance, velocity and displacements [2]. SMI changes the conditions for the threshold gain and phase and thus alter threshold current, differential quantum efficiency, laser power and wavelength. We have recently experimentally demonstrated SMI in a standard, commercially available, single-mode VCSEL as a means for measuring very small deflections of micrometer-sized cantilevers [3] (Fig. 1a). Here, we have numerically investigated SMI in an oxide aperture VCSEL to optimize the epitaxial structure for higher performance. The standard investigated structure is emitting light at $970 \mathrm{~nm}$ from $3 \mathrm{In}_{0.17} \mathrm{Ga}_{0.83} \mathrm{As} / \mathrm{GaAsP}$ QWs sandwiched between 36 pairs of bottom mirror and 23 pairs of top mirror $\left(\mathrm{Al}_{\mathrm{x}} \mathrm{Ga}_{1-\mathrm{x}} \mathrm{As}\right)$. The mirrors are doped with $\mathrm{N}_{\mathrm{p}}=2.5^{*} 10^{18}$ and $\mathrm{N}_{\mathrm{n}}=2.0^{*} 10^{18}$ and doping loss is accounted for when calculating the reflectivity.

The calculations are based on matrix multiplication for calculating effective reflectivity and transmission with external feedback, combined with a logarithmic gain model and standard laser rate equations. Thermal effects are not included. A weak effective external reflectivity of $0.02 \%$ (including coupling losses due to mode expansion in $35 \mu \mathrm{m}$ air) is used as external feedback on the top side of the VCSEL.

The self-mixing signal is measured by measuring the output power from the laser through both the top and bottom side. The modulation strength of the power self-mixing signal can be expressed by the visibility, $\mathrm{V}=\left(\mathrm{P}_{\max }-\mathrm{P}_{\min }\right) /\left(\mathrm{P}_{\max }-\mathrm{P}_{\min }\right)$. The visibility is directly proportional to the strength of the feedback [2], but for a fixed feedback the modulation strength is a strong function of the laser current peaking around the threshold and with a plateau at high currents, Fig. $1 \mathrm{~b}$. The peak visibility can be increased by decreasing the reflectivity of the mirror facing the feedback such that the laser effectively feels more feedback. However, this also increases the threshold losses and current and thus the maximum visibility will be limited by the maximum available gain before thermal effects hinder lasing. However, by increasing the number of quantum wells to $2 * 3$ in a $2 \lambda$-cavity, such that all wells experience the maximum optical field, the current threshold increase from lowering the mirror reflectivity can be minimized. This $2 * 3$ well configuration is possible because the laser will not be modulated at high speed.

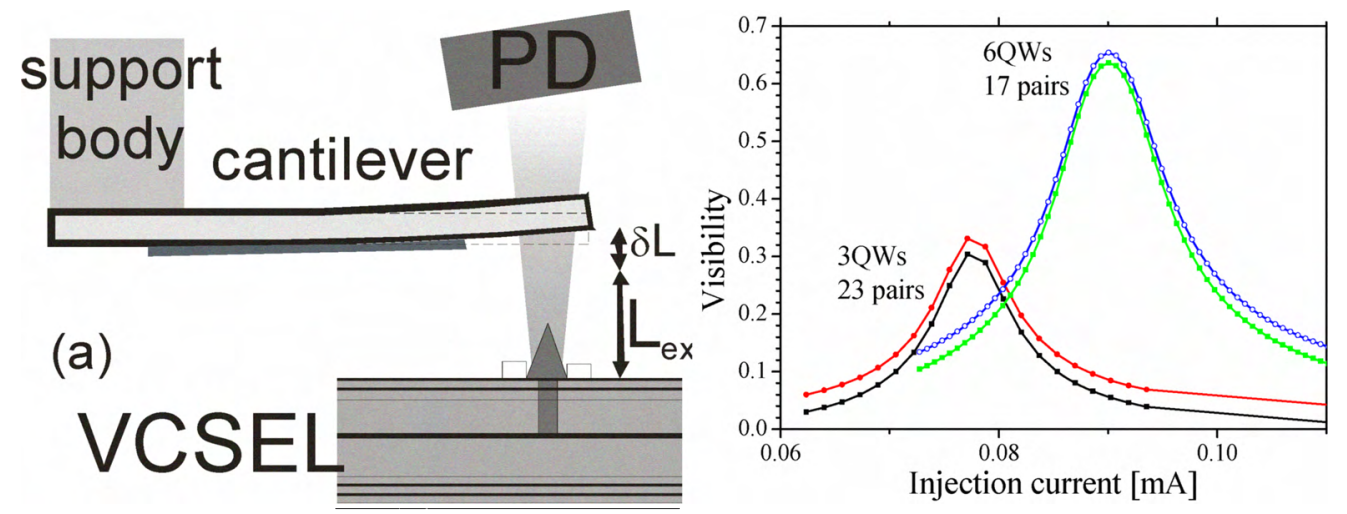

Fig. 1 a) Schematic of experimental set-up corresponding to the calculations in this paper. b) Plot of the visibility vs. injection current around threshold for three cases: a) 3 QWs with 23 top mirror pairs, b) 19 top mirror pairs, and c) 6 QWs with 17 top mirror pairs. Filled symbols: power from top mirror. Open symbols: power from bottom mirror.

As a summary we have shown how to improve the sensitivity towards self-mixing interference in VCSELs by simple epitaxial means and this should enable us to e.g. measure smaller bending deflections of cantilever sensors.

\section{References}

[1] U. Fiedler and K. Ebeling, "Design of VCSELs for Feedback Insensitive Data Transmission and External Cavity Mode-Locking", IEEE J. Sel. Top. Quant. Elec. 1, 442 (1995).

[2] P. J. de Groot, G. M. Gallatin, and S. H. Macomber, "Ranging and velocimetry signal generation in a backscatter-modulated laser diode," Appl. Optics 27, 4474 (1988)

[3] D. Larsson, A. Greve, J. M. Hvam, A. Boisen, and K. Yvind, "Self-mixing interferometry in vertical-cavity surface-emitting lasers for nanomechanical cantilever sensing, in review for APL. 